\title{
Overview: Application of Carbopol 940 in Gel
}

\author{
$* 1^{\text {st }}$ Fenny Indah Safitri \\ Faculty of Health \\ Universitas Harapan Bangsa \\ Purwokerto, Indonesia \\ fennyindahsafitri@gmail.com
}

\author{
$2^{\text {nd }}$ Desy Nawangsari \\ Faculty of Health \\ Universitas Harapan Bangsa \\ Purwokerto, Indonesia \\ desynawang9@gmail.com
}

\author{
$3^{\text {rd }}$ Dina Febrina \\ Faculty of Health \\ Universitas Harapan Bangsa \\ Purwokerto, Indonesia \\ febrinadina22@gmail.com
}

\begin{abstract}
Carbopol is an acrylic polymer. Carbopol is non-toxic and non-irritating so that it is suitable for gel preparations. Carbopol 940 is often used as a gelling agent in gel preparations. Concentration of carbopol 940 as a gelling agent needs to be concerned to obtain a good gel preparation. This study aimed to determine the effect of carbopol 940 concentration on physical properties, drug release and the use in eye drops. The research method used was descriptive method with data collection technique using PICO (Population, Intervention, Compare, Outcame) approach. Based on the Descriptive research results, it was obtained that carbopol 940 had influences on the physical properties of the gel in the form of $\mathrm{pH}$, viscosity, spreadability, adhesion, organoleptic and stability. Carbopol 940 is commonly used in controlled-release drug formulations. In addition, carbopol 940 is also safe to use in eye drops preparations which do not cause irritation in in vivo testing.
\end{abstract}

Keywords- Carbopol 940, Gelling agent, Physical properties, Drug release

\section{INTRODUCTION}

Gel, sometimes it is called as jelly, according to the fourth edition of Pharmacopoeia Indonesia, is a system consisting of two phases, namely the water phase and solids dispersed in liquid to form a semisolid system [1]. Several advantages of gel preparations compared to other topical preparations are that it can be easily applied and easily spread evenly when applying. It also provides a cool sensation and does not cause scars on the skin due to its transparent nature [2].

Gel formulations consist of active substances, gelling agents and other additives [3]. The concentration of the gelling agent must be selected appropriately as one of the determining parameters that can affect the nature and physical stability of the gel because it can affect the absorption of active substances on the skin [5]. One of the gelling agents often used is carbopol.Carbopol is an acrylic polymer. It is non-toxic and non-irritable with repeated use so that it is suitable for gel preparations [6]. It will form a transparent and bioadhesive gel [7].

The advantages of carbopol gelling agents are that they can be developed in room temperature water, unlike hydroxypropyl methylcellulose which needs to be developed in hot water. In addition, the selection of carbopol 940 is due to its large viscosity range of 40,000-60,000 $\mathrm{cP}[8]$. The concentration of carbopol 940 gelling agent directly affects the viscosity of the preparation which also affects the physical properties of the gel preparation [9].
The other gel component is the active substance. Active substances can affect the physical properties of gel preparations and their stability. The results of a study conducted by Bankar and Dole show the effect of the concentration of banana leaf extract (Musa acuminata) on the physical properties of gels using carbopol 940 gelling agent in which large extract concentration can increase the spreadability and viscosity [4]. The study shows that in addition to gelling agents, there are concentrations of extracts that affect the physical properties of the preparations. Each different active ingredient requires optimization of the gelling agent concentration. Therefore, research must be carried out of how the influence of carbopol 940 gelling agent on gel preparations in order to be able to do the right formulation and obtain a good preparation in physical properties and drug release.

\section{METHOD}

This was a systematic review research. This research was conducted by studying the literature and testing critical knowledge and related thought. The result of the study was used to answer the problem statements determined by the researchers. The data source of this research was secondary data obtained from the literature. Sources of information were obtained from the database of PubMed, ScienceDirect, and Google Scholar. Preliminary research results were used as a secondary data source by examining research relevant to the formulation of the problem. Data collection process used was data extraction method using PICO (Population, Intervention, Compare, Results). The strategic method was to find journals using keywords ("comparison of carbopol 940 compositions" or "carbopol 940; safety; carbopol 940" or "carbopol 940; eye preparation" or "drug release; carbopol $940 ") .16$ journals relevant to the aims of study were used to composed this literature. These journals contain physical properties, the release of gel preparations containing carbopol 940 and the safety of carbopol 940 in eye drops. Inclusion Criteria:

- Gel preparation of carbopol 940

- Carbopol 940 as a gel-forming agent

- The effect of carbopol 940 used in gel preparations

- Drug release of gel preparation of carbopol 940

Exclusion Criteria:

- Combination of carbopol 940 with other carbopol 
- Combination of carbopol 940 with non-polymeric material.

\section{RESULT}

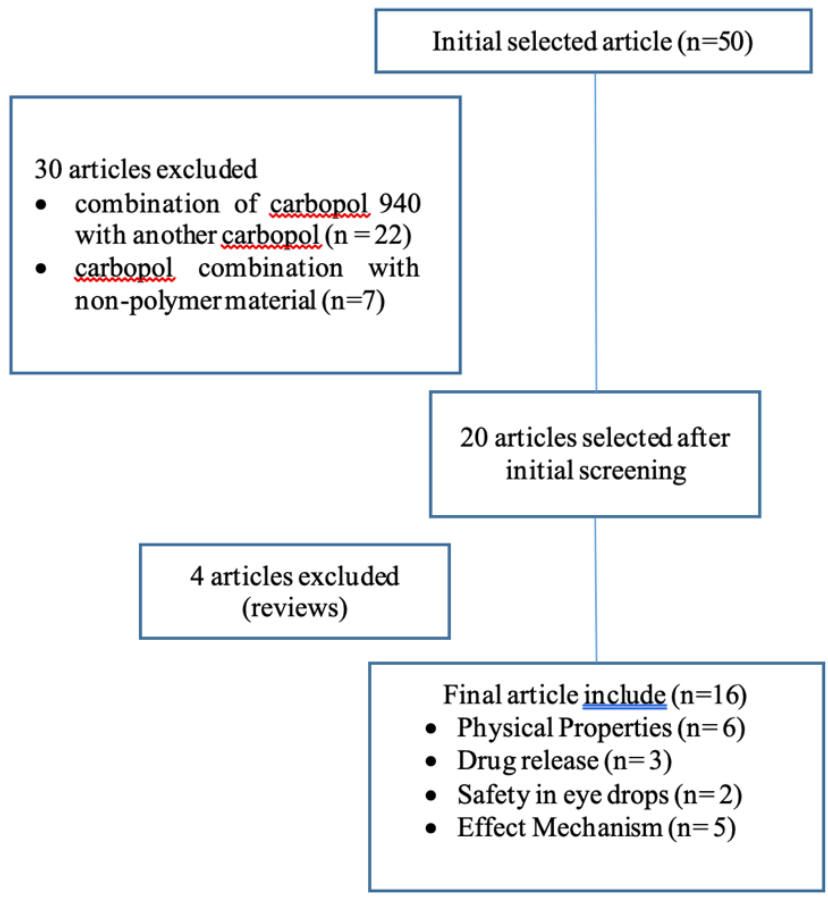

\begin{tabular}{|c|c|c|}
\hline No & $\begin{array}{c}\text { Author and } \\
\text { Method }\end{array}$ & Result \\
\hline 1 & $\begin{array}{l}\text { Asasutjarit[1 } \\
\text { 2] } \\
\text { Method: } \\
\text { Experiment }\end{array}$ & $\begin{array}{l}\text { Carbopol } 940 \text { added to in eye gel preparations } \\
\text { with a concentration of } 0.3 \% \text { has a pH of } 4.8 \pm \\
0.1 \text { while a concentration of } 0.1 \% \text { can produce } \\
\text { a dosage of } 5.4 \pm 0.1 \\
\text { carbopol } 940 \text { with a concentration of } 0.1 \% \text { can } \\
\text { be used as a safe gelling agent for eye drops } \\
\text { and has the advantage of being able to prolong } \\
\text { drug contact with the eye so that a better effect } \\
\text { is obtained } \\
\text { formulation using carbopol } 940 \text { at a } \\
\text { concentration of } 0.1 \% \text { tested in vitro in SIRC } \\
\text { cells showing a total score of } 0 \text { which means } \\
\text { no irritation at all. }\end{array}$ \\
\hline 2 & $\begin{array}{l}\text { Putriana[13] } \\
\text { Method: } \\
\text { Experiment }\end{array}$ & $\begin{array}{l}\text { chitosan gel with } 940 \text { carbopol gelling agents, } \\
\text { the result was pH 5.35 with carbopol } \\
\text { concentration } 1.5 \% \text {, obtained pH } 5.5 \text { at } \\
\text { carbopol } 940 \text { concentration } 1 \% \text { and pH } 6.25 \\
\text { with carbopol } 940 \text { concentration } 0.5 \%\end{array}$ \\
\hline 3 & $\begin{array}{l}\text { Rahmawati } \\
\text { and } \\
\text { Setiawan } \\
\text { [15] } \\
\text { Method: } \\
\text { Experiment }\end{array}$ & $\begin{array}{l}\text { carbopol } 940 \text { affects the viscosity of the gel } \\
\text { preparation with consecutive viscosity results } \\
\text { for a concentration of } 0.5 ; 1 ; 1,5 ; 2 \text {, namely } \\
130 \text { dpas, } 150 \text { dpas, } 175 \mathrm{dpas} \text {, and } 280 \text { dpas } \\
\text { the higher concentration of carbopol } 940 \mathrm{can} \\
\text { reduce the spreadability with the value of } \\
\text { scattering power respectively } 15,3887 \mathrm{~cm} \text {; } \\
10,7749 \mathrm{~cm} 10,139 \mathrm{~cm} 8,003 \mathrm{~cm} \text { at the } \\
\text { carbopol concentration } 9400.5 ; 1 ; 1.5 \text { and } 2 \text {. }\end{array}$ \\
\hline 4 & $\begin{array}{l}\text { Rahayu[16] } \\
\text { Method: } \\
\text { Experiment }\end{array}$ & $\begin{array}{l}\text { Carbopol } 940 \text { has a positive influence on the } \\
\text { viscosity of gel preparations with a coefficient } \\
\text { of carbopol } 940 \text { of } 6098 \text { compared to TEA } \\
\text { which has a negative effect with a TEA } \\
\text { coefficient of } 6960 \\
\text { carbopol } 940 \text { mixed with TEA has a positive } \\
\text { influence in gel formation with a coefficient } \\
\text { value of } 20869 \\
\text { carbopol } 940 \text { gives a positive response that is, } \\
\text { the coefficient value of } 0.315 \text { can increase the } \\
\text { adhesion greater than the effect of TEA }\end{array}$ \\
\hline
\end{tabular}

\begin{tabular}{|c|c|c|}
\hline & & $\begin{array}{l}\text { (0.244). Mixing between carbopol and TEA in } \\
\text { preparations shows a positive coefficient of } \\
0.035 \text {. } \\
\text { the stability of the gel showed a decrease in the } \\
\text { viscosity of the gel preparation with a carbide } \\
\text { concentration of } 9400.4 \% \text { for four weeks of } \\
\text { storage, so the gel can be said to be unstable. } \\
\text { The gel spread test results showed an increase } \\
\text { in the spreadability of the gel storage period } \\
\text { for four weeks. }\end{array}$ \\
\hline 5 & $\begin{array}{l}\text { Wijanti [18] } \\
\text { Method: } \\
\text { Experiment }\end{array}$ & $\begin{array}{l}\text { Formula } 1 \text {, Formula } 2 \text { and } 3 \text { meets the desired } \\
\text { adhesion specifications, while formula } 1 \text { does } \\
\text { not meet the desired specifications, because } \\
\text { there is a difference in the concentration of } \\
\text { carbopol } 940 \text { as a gelling agent, with the } \\
\text { concentration of carbopol } 940 \text { in formula } 1 \\
\text { being the lowest }(0.75 \%) \text { than formula } 2(1 \%) \\
\text { and } 3(1.5 \%) \text {. }\end{array}$ \\
\hline 6 & $\begin{array}{l}\text { Ningsi [21] } \\
\text { Method: } \\
\text { Experiment }\end{array}$ & $\begin{array}{l}\text { formula A with a concentration of } 0.5 \% \\
\text { carbopol } 940 \text { gel preparations in the form of } \\
\text { liquid while in formulas B, C, and D at a } \\
\text { concentration of } 1.25 \%, 2 \% \text { and } 2 \% \text { carbopol } \\
940 \text { gel preparations in the form of semisolid, } \\
\text { and on formula E, F, G, and Hatconcentrations } \\
\text { of } 3 \%, 4.5 \%, 6 \% \text {, and } 6 \% \text { are semisolid. } \\
\text { the greater the concentration of carbopol } 940 \text {, } \\
\text { the more different the clear color of the gel, the } \\
\text { typical aroma of glycerin decreases and the } \\
\text { texture is thicker. }\end{array}$ \\
\hline 7 & $\begin{array}{l}\text { Dambur[22] } \\
\text { Method: } \\
\text { Experiment }\end{array}$ & $\begin{array}{l}\text { changes in } \mathrm{pH} \text { that occur after storage because } \\
\text { it is influenced by the content of sericin protein } \\
\text { present in anti-acne gels that are stored at high } \\
\text { temperatures and the } \mathrm{pH} \text { of the gel to } 7.5 \text {, not } \\
\text { included in the range Skin pH 4.5- } 6.5 \text {. }\end{array}$ \\
\hline 8 & $\begin{array}{l}\text { Sun [23] } \\
\text { Method: } \\
\text { Experiment }\end{array}$ & $\begin{array}{l}\text { carbopol } 940 \text { is a good material for topical } \\
\text { delivery of tolterodine, giving a significantly } \\
\text { higher yield of drug release than carbopol } 934 \\
\text { and } 980 \text {. }\end{array}$ \\
\hline 9 & $\begin{array}{l}\text { Aslani[24] } \\
\text { Method: } \\
\text { Experiment }\end{array}$ & $\begin{array}{l}\text { Formula } 5 \text { containing } 1 \% \text { carbopol } 940 \text { and } 3 \% \\
\text { sodium CMC more mucoadhesive than } \\
\text { Formula } 4 \text { containing } 0.5 \% \text { carbopol } 940 \text { and } \\
3 \% \text { sodium CMC. }\end{array}$ \\
\hline 10 & $\begin{array}{l}\text { Jana [26] } \\
\text { Method: } \\
\text { Experiment }\end{array}$ & $\begin{array}{l}\text { aceclofenac formulation using a carbopol } 940 \\
\text { gelling agent showed continuous aceclofenac } \\
\text { permeation for more than } 8 \text { hours ex vivo } \\
\text { using rat skin. Anti-inflammatory activity in } \\
\text { vivo in carrageenan-induced mice also showed } \\
\text { a higher ratio of more than } 4 \text { hours in edema of } \\
\text { mouse feet prepared with carbopol } 940 \text { as } \\
\text { gelling agents compared to that of the } \\
\text { marketed aceclofenac gel. }\end{array}$ \\
\hline 11 & $\begin{array}{l}\text { Song [27] } \\
\text { Method: } \\
\text { Experiment }\end{array}$ & $\begin{array}{l}\text { eye drops containing } 9400.1 \% \text { carbopol } \\
\text { gelling agent and HPMC } 0.4 \% \text { were evaluated } \\
\text { by Draize method and histopathological test on } \\
\text { rabbit eye cornea. The results of the Draize } \\
\text { method obtained irritation scores for each } \\
\text { group of formulations were less than } 2.5 \text {, } \\
\text { which indicated that the formulations were } \\
\text { well tolerated. The histopathological test found } \\
\text { no corneal degeneration, necrosis, } \\
\text { inflammation, or edema in the cornea of the } \\
\text { eye. }\end{array}$ \\
\hline
\end{tabular}

\section{DISCUSSION}

\section{A. Effect of Carbopol 940 on the Physical Properties of Gel Preparations}

This gel-forming agent has an influence on the physical properties of the gel preparation.

- $p H$. The $\mathrm{pH}$ test was aimed to see the acidity of the preparation to ensure it did not cause irritation to the 
skin [10]. The $\mathrm{pH}$ standard for topical preparations suitable with skin $\mathrm{pH}$ balance is 4.5-6.5 [11]. According to research conducted by Asasutjaritcarbopol 940 added to eye drops in-situ gel with a concentration of $0.3 \%$ had a $\mathrm{pH}$ of $4.8 \pm 0.1$. Meanwhile, a concentration of $0.1 \%$ could produce a $\mathrm{pH}$ of $5.4 \pm 0.1$ [12]. In the research on making chitosan gel with carbopol 940 gel-forming agents, the result showed $\mathrm{pH}$ of 5.35 with a carbopol concentration of $1.5 \%$, It was obtained $\mathrm{pH}$ of 5.5 with carbopol 940 concentration of $1 \%$ and $\mathrm{pH}$ of 6.25 was showed with carbopol concentration of $0.5 \%$ [13]. The effect of carbopol $940 \mathrm{on} \mathrm{pH}$ is that the higher the concentration of carbopol 940, the more acidic the $\mathrm{pH}$ of the gel produced because carbopol 940 has acidic properties [6]. Carbopol 940 can form a good and stable gel matrix at a neutral $\mathrm{pH}$ around 6-11 [6]. When carbopol 940 is dispersed it will have an acidic $\mathrm{pH}$ and still not form a good matrix gel. After being neutralized by alkylating agents (e.g. $\mathrm{NaOH}$ and Triethanolamine) the polymer will absorb and hold water, the polymer chains are interconnected with cross bonds to form a good gel mass [14].

- Viscosity. Viscosity is one of the physical properties of the preparation associated with the thickness of the gel preparation. According to research conducted by Rahmawati and Setiawan, it showed that carbopol 940 affected the viscosity of gel preparations with consecutive viscosity results for concentrations of $0.5 ; 1 ; 1,5 ; 2$, namely 130 dpas, 150 dpas, 175 dpas and 280 dpas [15]. The results of research conducted with the Simplex Lattice Design (SLD) method showed that carbopol 940 had a positive effect on the viscosity of gel preparations with a carbopol 940 coefficient of from 6098 compared to Triethanolamine which had a negative effect with a TEA coefficient of 6960 [16]. The function of TEA here is not as a gelling agent but as an alkylating agent related to the formation of $\mathrm{pH}$ and gel matrix through the formation of polymer chain [14]. SLD research results also showed that carbopol 940 mixed with TEA had a positive effect on gel formation with a coefficient value of 20869 [16]. ). The mechanism of gel formation by carbopol as a gel forming agent is by binding the solvent to the structure of the carbopol polymer so that cross-linking occurs in the polymers which causes water to be trapped inside, then the trap occurs and holds the solvent molecule to form a rigid structure resistant to certain forces and pressures [17]. Thus, the higher the level of carbopol 940 the higher the viscosity and the resulting preparation will have high viscosity.

- Adhesiveness. Adhesion is a physical parameter of the gel preparation which aims to ensure that the preparation gel can adhere well to the skin when used [18]. According to research conducted by Wijayantiadhesion test to the preparations between formulas with statistical analysis (the interval confidence of $95 \% \mathrm{~F}_{\text {Count }}(80311)>\mathrm{F}_{\text {Table }}(2.53)$ so that there were significant differences between formulas. Formula 2 and 3 met the desired adhesion specifications, while formula 1 did not meet desirable specifications, this was due to differences in the concentration of carbopol 940 as a gel forming agent, the concentration of carbopol 940 in formula 1 is the lowest $(0.75 \%)$ compared to formula $2(1 \%)$ and 3 (1.5\%) [18]. The research conducted with SLD method was obtained the simplex lattice design equation $\mathrm{Y}=0.315(\mathrm{~A})+0.244(\mathrm{~B})+0.035(\mathrm{~A})(\mathrm{B})$ which showed that the proportion of carbopol 940 gives a positive response with a coefficient value of 0.315 which can increase great adhesion compared to TEA (0.244). Mixing between carbopol 940 and TEA in the preparation showed a positive coefficient value of 0.035 , both of these components were able to increase the value of the adhesion of gel preparations [16]. Carbopol 940 consists of long chain polymers. When it has high concentrations it will increase the viscosity. This viscosity is directly proportional to adhesion. The higher the viscosity of a preparation, the greater the adhesion.

- Spread of Power. The extent of spread causes contact between the drug and the skin becomes extensive. Therefore, the absorption of the drug to the skin occurs quickly [19]. The SLD equation for the spread response in research conducted by Rahayushowed the comparison of the proportion of TEA (7.52) was able to provide a positive response to increase the spread value of the gel compared to carbopol (3.45) [16]. Mixing between the components of the carbopol fraction and the TEA fraction gave a negative response with a coefficient of 5.19 for the response of the gel spreadability [16]. In other research, it was also found that the higher concentration of carbopol 940 could reduce the spreadability with consecutive value of $15.33887 \mathrm{~cm} ; 10,7749 \mathrm{~cm} ; 10,139 \mathrm{~cm}$; $8.003 \mathrm{~cm}$ at carbopol concentration of $9400.5 ; 1 ; 1.5$ and 2 [15]. Spreadability also relates to viscosity of a preparation. Spreadibility is inversely proportional to viscosity. The higher the viscosity the lower the spreadbility which is produced. Conversely, the lower the viscosity the higher the power spreadbility which is produced higher the power produced [20].

- Organoleptic. Organoleptic observation was carried out by inspecting changes in shape, color, and odor of the gel preparation [15]. The results of observations of dosage form of gel formulas A with a concentration of $0.5 \%$ carbopol 940 gel formulas was in topical formulations. Meanwhile, in formulas B, C and $\mathrm{D}$ at concentrations of $1.25 \%, 2 \%$ and $2 \%$ carbopol 940 were in semi-solid gel formulations, and on formulas $\mathrm{E}, \mathrm{F}, \mathrm{G}$ and $\mathrm{H}$ in the composition of $3 \%$, $4.5 \%, 6 \%$ and $6 \%$ were in semi-solid form [21]. According to research conducted by Ningsiin making hair gel preparations, the greater the concentration of carbopol 940, the more different the color of the clear gel, the typical aroma of glycerin was increasing and the texture was getting thicker [21]. Based on research, carbopol 940 affected the organoleptic of a gel preparation. The greater the concentration of carbopol940 the more dense or thick the gel preparation, the more concentrated color according to 
the color of the active ingredient used, and the less the smell of the active ingredient or other substances.

- Stability. Stability can be determined as a parameter in which the product to survive within a specified limit during the retention period and use, nature and characteristics are the same as when a preparation is made [1]. The results of studies regarding to gel stability showed a decrease in the viscosity of the gel preparation with carbopol 940 concentration of $0.4 \%$ at four weeks retention, so that the gel remained unstable. The gel dispersion test results showed an increase in the spreadability of the gel during retention period for four weeks[16]. This could occur due to the level of carbopol used $(0.4 \%)$, below the recommended range of carbopol use as gelling agent $(0.5-2 \%)$ [6]. Meanwhile, the spreadability increases because it is inversely proportional to the thickness of the gel preparation [20]. An accelerated experiment carried out by DamburpH changes occurred after retention period due to the influence of the sericin protein content in the anti-acne gel stored at high temperatures causing the gel increased at $\mathrm{pH} 7.5$, out of the range of skin $\mathrm{pH}, 4,5-6,5$ [22]. To sum up, $\mathrm{pH}$ affects the stability of the carbopol gel preparation as the increasing $\mathrm{pH}$ can increase the viscosity of gel preparations which affect other physical properties such as spreadability and adhesion. Therefore, it is necessary to adjust the level of carbopol 940 as gelling-agent for each different active substance. In addition, the carbopol 940 content exceeds the grading level $(0.5-2 \%)$ for the gelling agent can also influence the availability of existing gel preparations.

\section{B. Drug release with carbopol 940 as gelling agent}

Drug release is an important thing that needs to be concerned so that drugs or active substances can enter the body and cause effects. Carbopol 940 as a gelling-agent can influence drug release. Sun reported that the release of tolterodine drug increased relatively constant for 12 hours. Carbopol 940 gel matrix could significantly increase the cumulative amount of percutaneous drugs. These results indicate that carbopol 940 is a good material for topical carrier of tolterodine. Besides, it gives a significantly higher yield of drug release than that of carbopol 934 and 980 [23].

The results of mucoadhesive strength measurement with a modified tensiometer showed Formula 5 containing $1 \%$ carbopol 940 and 3\% Sodium Carboxymethylcellulosa ( $\mathrm{Na}$ CMC) is more than Formula 4 containing 0.5\% carbopol 940 and 3\% Sodium Carboxymethylcellulosa (Na CMC). It indicates that the increasing concentration of carbopol 940 can increase mucoadhesion. Carbopol has a high molecular weight and it can expand up to 1000 times its original volume so that it can make a surface adhere to mucin and provide a good mucoadhesive effect [24].

Carbopol forms a secondary bioadhesive bond with mucin, meanwhile other polymers form superficial adhesion [25]. Increasing the concentration of carbopol 940 can reduce the rate of drug release due to an increase in viscosity. The main factors in determining the rate of drug release and bioadhesive effects are hydrogel hydration and swelling. Hydration and swelling depend on the degree of polymer crosslinking. It was observed that the level of cross-linking in carbopol 940 was high [24]. Increasing the amount of polymer gel becomes thicker and water penetration is limited, causing a reduction in drug release but it can increase the contact time of the drug [25]. Jana reported that an aceclofenac formulation using a carbopol 940 gellingagent showed continuous aceclofenac permeation for more than 8 hours ex vivo using rat skin [26]. Anti-inflammatory activity in vivo in carrageenan-induced mice also showed a higher ratio of more than 4 hours in edema of mouse feet prepared with carbopol 940 gelling-agents compared to commercial aceclofenac gel. From sort of studies the carbopol 940 gelling agent can be used to formulate controlled release drugs [26].

\section{Safety of carbopol 940 in Eye Drops}

Asasutjaritreported eye drop formulations using carbopol 940 at a concentration of $0.1 \%$ tested in vitro in SIRC cells. The results of the percentage of cell viability (\% cell viability) of SIRC cells exposed to $5 \%$ obtained a score of 0 and SIRC cells exposed to $0.05 \%$ obtained a score of 1 . Therefore, it can be classified into minimum irritation. Then the formula is tested in vivo on rabbits using the modified draize test method showing a total score of 0 which means no irritation at all [12].

Song conducted a histopathology test and an irritation test using the eye drops preparation draize method containing carbopol 940 gelling-agent of $0.1 \%$. well. In histopathology test no corneal degeneration, necrosis, inflammation, or edema in the cornea of the eye were found [27].

The research report showed that carbopol 940 with a concentration of $0.1 \%$ can be used as a safe gelling-agent for eye drops and has the advantage of being able to prolong drug contact with the eye so that a better effect is obtained. It was found that the maximum concentration of diclofenac sodium in aqueous humor of rabbit with carbopol 940 gelling-agent of $0.1 \%$ was 2.2 times higher than commercial eye drops which showed 1.7 times [12]. This is because carbopol 940 can increase the viscosity of eye drops so that it can have a mucoadhesive effect when used. The mechanism of in vitro release depends on two processes, namely the migration of water into the in situ gel-forming system and drug diffusion. Prolonged release is caused by the formation of hydrogen bonds between the drug and the polymer, which has helped in controlling the rate of drug release [27].

\section{CONCLUSION}

Carbopol 940 is a gelling-agent which can affect the physical properties of gel preparations. The concentration of carbopol 940 as a gelling-agent can be varied to produce preparations that meet the criteria for gel physical properties namely $\mathrm{pH}$, viscosity, adhesion, spreadability, organoleptic and stability. Carbopol 940 can affect the release of active drug substances by their viscosity value. The higher the viscosity of a preparation, the more difficult the drug is released. This makes the use of carbopol 940 more focused on controlled release preparations. Eye drops are an example of a controlled release using carbopol 940 as a gelling-agent that can increase the contact time of the drug with the eye so that it can increase drug absorption. The use of carbopol 940 in eye drops is relatively safe to use because it does not cause 
irritation and histopathology tests do not indicate damage to the cornea of the eye.

\section{ACKNOWLEDGMENT}

Acknowledgments were conveyed by researchers to the DwiPuspita Education Foundation through the Harapan Bangsa University Research Institute which funded this research.

\section{REFERENCES}

[1] Depkes, RI. (1995). Farmakope Indonesia Edisi 4. Departemen Kesehatan RepublikIndonesia.

[2] Anggraeni, Y., Hendradi, E. and Purwanti, T. (2012). DiklofenakdalamSistemNiosomdengan Basis Gel. PharmaScentia. 1(1). pp.1-15.

[3] Sanghi, D. K. and Tiwle, R. (2016). Formulation and Characterization of Herbal Face Wash/Scruber. European Journal of Pharmaceutical and Medical Research. 3(11). pp. 274-278.

[4] Bankar, A. M. and Dole, M. N. (2016). Formulation and evaluation of herbal antimicrobial gel containing musaacuminata leaves extract. Journal of Pharmacognosy and Phytochemistry. 5(1). pp.1-3.

[5] Sudjono(2012).PengaruhKonsentrasiGellingAgentCarbomer934danH PMCPadaFormulasi Gel Lender Bekicot (Achatina Fulica) TerhadapKecepatanPenyembuhan Luka Baka Pada PunggungKelinci. Pharmacon. 13(1). pp.6-11.

[6] Rowe, R., Sheskey, P. J. and Quinn, M. (2009). Carbomer. Handbook of Pharmaceutical Excipients.

[7] Buchan, B. et al. (2010). Gel Formulations forTreatment of The Ophthalmic Complications in Cystinosis. International Journal of Pharmaceutics. Elsevier B.V. pp. 1-6. doi: 10.1016/j.ijpharm.2010.03.065

[8] Shu, M. (2013). Formulasisediaan gel. JurnallmiahMahasiswaUniversitas Surabaya. 2(1). pp. 1-14.

[9] Samala,M.L.andSridevi,G.(2016).RoleofPolymersasGellingAgentsint heFormulationof Emulgels. Polymer science. 2(1). pp. 1-8. doi:10.4172/2471-9935.100010.

[10] Mappa, T., Jaya, E. H. and Novel, K. (2013). Formulasi Gel EkstrakDaunSasaladahan (Peperomia pellucida (L.) H.B.K) dan Uji EfektifitasnyaTerhadap Luka Bakar Pada Kelinci (OryctolagusCuniculus).PHARMACONJurnalIlmiahFarmasiUNSRATVol.2No.02Hal 49-55. 2(02). pp.49-56.

[11] Kuncari, S. E., Iskandarsyah and Praptiwi (2014). Evaluasi, Uji StabiltasFisik dan SsineresisSediaan Gel yang MengandungMinoksidil Apigenin dan PerasanHerbaSeledri(Apiumgraveolens $\quad$ L.). BuletinPenelitian Kesehatan. 42(4). pp.213-222.

[12] Asasutjarit, R. et al. (2011). Optimization and Evaluation of Thermoresponsive Diclofenac Sodium Ophthalmic in situ Gels. International Journal of Pharmaceutics. Elsevier B.V. 411(1-2), pp. 128-135. doi:10.1016/j.ijpharm.2011.03.054.

[13] Putriana, N. A., Rusdiana, T. and Prakoso, M. A. A. (2019). Formulation and Phisical Stability Testing of Chitosan Gel from Vaname Shrimp Shell (Litopenaeusvannamei) with Carbopol 940
Gelling Agent. Indonesian Journal of Pharmaceutics. 1(3). pp. 1-5. doi: 10.24198/idjp.v1i3.21556.

[14] Varges, P. R. et al. (2019). Rheological characterization of carbopol (B) dispersions in water and in water/glycerol solutions. Fluids. 4(1). doi:10.3390/fluids4010003.

[15] Rahmawati, D. A. and Setiawan, I. (2019). The Formulation and Physical Stability Test of Gel Fruit Strawberry Extract (Fragaria $x$ ananassaDuch.). pp.38-46.

[16] Rahayu, T., Fudholi, A. and Fitria, A. (2016) 'OptimasiFormulasi Gel EkstrakDaunTembakau (Nicotiana Tabacum) DenganVariasi Kadar Karbopo1940 Dan Tea MenggunakanMetode Simplex Lattice Design (Sld). JurnalImiahFarmasi. 12(1). pp. 22-34. doi: 10.20885/jif.vol12.iss1.art3.

[17] Martin, A., Swarbick, J., dan A. C. (1993). FarmasiFisik 2 Edisi III. Jakarta: UIPress.

[18] Wijayanti, L. P., Darsono, F. L. and Ervina, M. (2017). PenggunaanCarbormer 940 sebagai Gelling Agent dalam Formula Pasta Gigi EkstrakBuahApel (Malus sylvestris Mill) dalamBentuk Gel. Journal of Pharmacey Science and Practice. 4(1). pp.11-17.

[19] Wibowo, S. A., Budiman, A. and Dwi, H. (2017). Formulasi dan Aktivitas Anti JamurSediaanKrim M/A EkstrakEtanolBuahTakokak (Solanum Torvum Swartz) Terhadap Candida Albicans. JurnalRisetSains dan Teknologi. 1(1). pp.22-36.

[20] Garg, A. et al. (2002). Spreading of Semisolid Formulations: An Update. Pharmaceutical Technology North America. 26(9). pp.84105.

[21] Ningsi, S., Leboe, D. and Armaya, S. (2016) 'Formulasi Dan Uji StabilitasFisik Gel EkstrakDaunBinahong (Andrederacordifolia). FakultasIlmu Kesehatan Universitas Islam Negeri Alauddin Makassar. 4(1). pp. 21-27.

[22] Dambur, M. et al. (2019). Formulasi Dan PengujianStabilitasFisik Gel AntijerawatLiofilisatLimbahKokonAsalKabupatenSoppeng. Pharmacy Medical Journa. 2(2). pp.70-74.

[23] Sun, F. et al. (2013). Preparation, Characterization and Pharmacological Evaluation of Tolterodine Hydrogels for the Treatment of Overactive Bladder. International Journal of Pharmaceutics. $454(1) . \quad$ pp. 532-538. doi:10.1016/j.ijpharm.2013.07.041.

[24] Aslani, A., Ghannadi, A. and Najafi, H. (2013). Design, formulation and evaluation of a mucoadhesive gel from Quercus brantii L. and coriandrum sativum L. as periodontal drug delivery. Advanced Biomedical Research. 2(1). p. 21. doi:10.4103/2277-9175.108007.

[25] Bukka, R., Prakasam, K. and Patel, C. D. (2010). Preparation and Evaluation of Intraoral Drug Delivery System for Rasagiline mesylate. International Journal of Pharmaceutical Sciences and Drug Research. 2(4). pp.294-301.

[26] Jana, S. et al. (2014). Carbopol gel containing chitosan-egg albumin nanoparticles for transdermal aceclofenac delivery. Colloids and Surfaces B: Biointerfaces. Elsevier B.V.114. pp. 36-44. doi:10.1016/j.colsurfb.2013.09.045

[27] Song, J. et al. (2013). Preparation and evaluation of sinomenine hydrochloride in situ gel for uveitis treatment. International Immunopharmacology. The Authors, 17(1), pp. 99-107. doi: 10.1016/j.intimp.2013.05.020 